\title{
FENOMENOLOGI DAKWAH (Dakwah dalam Paradigma Sosial Budaya)
}

\author{
M. Fuad Anwar ${ }^{1}$ \\ funawar@gmail.com
}

\begin{abstract}
ABSTRAK
Ilmu dakwah secara dikhotomi adalah bagian dari ilmu-ilmu sosial, yang berkaitan erat dengan masalah-masalah manusia dengan masayarakat sekitarnya, baik dalam rangka interaksi kehidupan beragama, berkepercayaan dan beribadah, maupun dalam rangka mengkomunikasikan ajaran-ajaran agama kepada penganutnya, Paradigma sosial budaya adalah salah satu perspektif yang berkaitan dengan latar kehidupan sosial masayarakat dan sistem budayanya. Pola dakwah sosial budaya dengan pendekatan fenomenologi dapat diterapkan melalui berbagai macam media pengajian ceramah agama dan lain-lain, dakwah fenomenologi adalah pola dakwah yang sangat memperhatikan aspek pemahaman masyarakat dalam konteks kegiatan dakwah dakwah
\end{abstract}

Kata Kunci: Dakwah, Sosial, Fenomenologi

\begin{abstract}
Preaching science in dichotomy is part of the social sciences, which are closely related to human problems with the surrounding community, both in the context of the interaction of religious life, berekepyaanan and worship, as well as in communicating religious teachings to adherents, social cultural paradigm is one perspective related to the background of the social life of the society and its cultural systems. The socio-cultural propaganda pattern with a phenomenological approach can be applied through various kinds of religious lecture recitation media and others. da'wah da'wah activities
\end{abstract}

Keywords: Da'wah, Social, Phenomenology

\footnotetext{
${ }^{1}$ Dosen Fakultas Ushuluddin Adab dan Dakwah IAIN Syekh Nurjat Cirebon
} 


\section{A.Pendahuluan}

Kata dakwah berasal dari Bahasa Arab yang berarti, ajakan, seruan, panggilan, undangan. Illmu dakwah secara umum adalah ilmu pengetahuan yang berisi cara-cara tuntunan, bagaimana menarik perhatian manusia untuk menganut, menyetujui, melaksanakan suatun ideologi, pendapat pekerjaan tertentu. Ilmu Dakwah juga berarti mengajak manusia dengan cara bijaksana ke jalan yang benar sesuai dengan perintah Tuhan, untuk kemaslahatan dan kebahagiaan mereka di dunia dan akherat, (Toha Yahya Omar: 1992:1).

Dakwah pada hakikatnya adatah ajakan atau seruan untuk melakukan perubahan dari suatu keadaan yang tidak dikehendaki, kepada situasi di-kehendaki sesuai dengan norma dan nilai-nilai ajaran agama, yang ber-sumber dari Al-Qur'an itu.

Dakwah sebagai suatu seruan membutuhkan suatu teknik dan strategi komunikasi yang berkaitan dengan tugas utamanya. Tuntutan mempunyai kemampuan komunikasi, informasi, dan teknologi dan pendekatan-pendekatan dalam ilmu sosial dan budaya dalam berdakwah menjadi sangat mutlak ketika masyarakat atau umat dalam era global seperti sekarang sudah tidak lagi dibatasi oleh dindingdinding ruang dan waktu. Umat atau masyarakat sudah semakin tersebar ke segala tempat dan penjuru, membutuhkan penguasam ilmu-ilmu sosial seperti, sosiologi, antropologi, psikologi, dan komunikasi masa yang handal, agar dakwah sebagai salah satu wujud komunikasi dapat disempurnakan tepat sasaran, sesuai misi dan visinya. Dengan bekal ilmu pengetahuan dan ilmu-ilmu di atas seorang da'i akan mampu mengidentifikasi serangkaian masalah yang terdapat pada semua peringkat masyarakat, antara lain meliputi pertanyaan-pertanyaan yang lebih dahulu harus dipelajari.

Paradigma sosial budaya adalah salah satu perspektif yang berkaitan dengan latar kehidupan sosial masyarakat dan sistim budayanya. Tulisan yang singkat ini sedikit akan membahas bagaimana pola dakwah sosial budaya dengan pendekatan fenomenologi dapat diterapkan melalui berbagai macam media pengajian ceramah agama dan lain-lain, dakwah fenomenologi adalah pola dakwah yang sangat memperhatikan aspek pemahaman masyarakat dalam konteks kegiatan dakwah dakwah.

\section{B. Realisme dan Idealisme}


Perdebatan filsafat tidak ubah-nya seperti debat kusir dan mem-bosankan. Sebab apabila kita simak maka mereka (berbagai kelompok pemikiran) itu tidak ada yang mau dan ingin merobah pendiriannya. Mereka kalau tidak Idealisme atau Rasionalisme mereka akan memosisikan diri menjadi Empirisme atau Realisme. Di mana itu semua sebenarnya terjadi karena problema posisi "Subjek" (yang berpikir, bertindak, mengetahui, berkesadaran, manusia) dan "Objek" (yang dipikirkan, ditindaki atau diekplorasi, diketahui atau dianalisa, tidak ber-kesadaran, lingkungan di luar manusia).

Idealisme atau Rasionalisme mengatakan bahwa apapun yang kita ketahui itu sama dengan apa yang kita miliki dalam roh/jiwa, apa yang diluar kita hanya klarifikasi, apa-apa yang sudah kita ketahui dalam jiwa/roh. Sehingga tidak ada realitas yang ter-lepas dari roh. Ada yang berpikir ekstrem "Yang ada adalah yang terfikirkan". Terjadi di sini Subjektivitas absolut. Dimulai oleh Plato, dan kelompok ini antara lain: Descartes, Spinoza, Leibnis, Immanuel Kant, Hegel, dan lainlain.

Sedangkan Realisme atau Empirisme mengatakan ada hal-hal yang riil/di luar kita, sedangkan kita mengetahui itu lewat persepsi atau penampakan. "Realitas" diketahui sebagai suatu yang tertutup dan bergantung pada manusia. Dan kemampuan atau pengetahuan kita itu di-asalkan dari hal-hal yang riel itu. Diawali oleh Aristoteles, diteruskan oleh Berkeley, David Hume, Francis Bacon, Positivisme, dan lain-lain.

Intinya adalah sekalipun berbeda, perdebatan itu tetap beranggapan bahwa kita dapat mengetahui realitas itu dengan sepenuhnya secara tuntas. Sekalipun Kant mencoba menjembatani kedua perdebatan tersebut dengan ke-14 kategorinya dengan susunan pemikiran (analitis, sintetis aposteori, dan sintetis apriori). Dan membagi antara "ada dalam dirinya" (das ding an sih = Neomena) dan ada yang dapat kita ketahui (Das ding fur Mich = fenomena), Tetapi tetap ia terjebak ke dalam Idealisme/rasionalisme yang cukup ekstrem. Perdebatan itu mulai ada variasinya setelah keluarnya ahli matematika Edmund Husserl dengan Filsafat dan Metode Fenomenologinya.

\section{C.Pengertian Fenomenologi}

Secara etimologis, Fenomenologi dari asal kata Fenomen, 
inggris: Phenomenon; Yunani: Phainomenon (apa yang tampak) dari Phaonesthai-/Phainomai/Phainein (menampakkam, memperlihatkan). Artinya adalah: Objek persepsi $($ baca $=$ apa yang diamati), apa yang tanpak pada kesadaran kita. Objek pengalaman Indrawi (apa yang tampak pada panca indra kita). Suatu fakta atau peristiwa yang dapat diamati.

Kant mengatakan, bahwa kita hanya bisa mengetahui sesuatu itu lewat penampakannya saja. Sedangkan benda itu sendiri sebagai dirinya (neomenon) tidak mampu kita ketahui. Yang dapat kita ketahui adalah ia (benda itu) sebagai objek, gejala, fenomena.

Fenomenologi bukan suatu sistem atau aliran filsafat, juga bukan suatu disiplin ilmu. M.A.W. Brouwer menyebutkan bahwa; jika melihat karya-karya Husserl, bisa diperoleh gambaran bahwa fenomenologi itu suatu pendekatan atau cara melihat sesuatu MarleauPonty menjelaskan fenomenologi sebagai filsafat yang berusaha mengembalikan essensi ke-dalam eksistensi, suatu filsafat yang tidak mengharapkan akan sampai kepada pemahaman manusia kecuali dengan bertitik tolak dari faktisitas manusia. Ponty juga menyebut fenomenologi sebagai metode pemahaman manusia dengan cara mendeskripsikan pengalamanpengalaman manusia sebagaimana adanya. Sedangkan Hall dan Lindzey mengatakan fenomenologi sebagai metode pendiskripsian data dari pe-ngalaman segera (immediate ex-perience), suatu metode yang di-tujukan untuk 'memahami' ketimbang 'menerangkan' fenomena.

Seperti kata Misiak dan Sexton, setiap Eksistensialis adalah fenomenolog, yakni menganalisa situasi keberadaan manusia melalui pengamatan langsung atas pengalaman manusia. Tetapi tidak semua fenomenologi adalah Eksistensialis.

Fenomenalisme adalah pandangan yang mengatakan; 1) Hanya fenomena (data inderawi) dapat diketahui sebagaimana fenomena tersebut tampak kepada kesadaran kita, 2) Kita tidak dapat mengetahui hakikat terdalam dari suatu kenyataan yang berada di dalam dirinya sendiri. 3) Apa yang kita ketahui tergantung pada kegiatan kesadaran. Realitas obyek lahiriah, fisis berdasarkan pengamatan, pencerapan seseorang. 4) Pengetahuan dibatasi pada apa yang dapat dicerap (diamati secara sadar terhadap dunia luar dan dibatasi pada apa yang dapat dicerap dengan introspeksi tentang kegiatan dan keadaan mental kita. 
5) Realitas merupakan totalitas pengalaman-pengalaman sadar yang mungkin ada. 6) Materi merupakan kemungkinan permanen bagi pencerapan (sensasi). Obyek-obyek material merupakan rangkaian atau gugusan kelompok cerapan inderawi yang aktual atau yang mungkin. Dunia fisik tidak dapat dikatakan terpisah dari data inderawi seorang pengamat, baik yang aktual maupun yang bersifat potensial. 7) Obyek fisik (material) merupakan konstruksi logis berdasarkan persepsi (data indrawi). Arti pernyataan tentang obyek fisik, seluruhnya dapat dianalisis dalam kaitan dengan pernyataan tentang pola-pola data inderawi, atau seluruhnya dapat dikembalikan kepada pernyataan tentang pola-pola data inderawi (fenomena). 8) Berbeda dengan idealisme epistemologis, fenomenalisme dalam arti yang tepat menegaskan dan menandaskan eksistensi segala sesuatu yang terlepas dari pikiran (berbeda dengan idealisme Hegel). Tetapi hakikat segala sesuatu yang berada dalam dirinya sendiri tetap tidak dapat kita ketahui (sama dengan Immanuel Kant). Di sini pula letak perbedaan antara realisme dan fenomenalisme. Kaum fenomenalis menegaskan bahwa segala sesuatu memberikan kesan-kesan kepada kita. Dalam kesan-kesan ini, segala sesuatu tampak kepada kita sesuai dengan ciri khas subyek bersangkutan.

Dan gejala (kesan) yang kita terima secara pasif ini merupakan obyek pengetahuan kita. Oleh karena itu, fenomenalisme berbeda baik dengan realisme maupun dengan idealisme. Idealisme mengatakan bahwa obyek pengetahuan dihasilkan secara aktif oleh pikiran kita. Karena kesankesan atau gejala berbeda sesuai dengan kekhususan masing-masing subyek dan karena bagi fenomenalisme, yang benar adalah apa yang tampak, maka fenomenalisme - dilihat dan sudut logika - merupakan suatu bentuk relativisme. Fenomenologi yaitu Ilmu tentang fenomen-fenomen atau apa saja yang tampak (filsafat yang berpusat pada analisis terhadap gejala-gejala yang membanjiri kita.

\section{D.Dakwah \\ Fenomenologi}

Interaktif

Pola dakwah interaktif fenomenologis adalah model penyampaian pesan ajaran agama secara dialogis, di rnana da'i atau juru dakwah secara terbuka berkomunikasi timbal balik dengan masyarakat sebagai obyek dakwah. Masyarakat secara terbuka dapat menyampaikan masalah-masalah 
aktual yang mungkin sangat urgen bagi kehidupan mereka, dan para da'i selalu siap untuk memberikan jawaban memperkuat iman dan taqwanya kepada Allah SWT.

Melalui interaksi fenomenologi para da'i dituntut untuk memahami makna prilaku masyarakat yang dijadikan sasaran dakwahnya, sehingga tercipta "Jembatan rasa antara juru dakwah sebagai agent of reformation dengan masyarakat yang menjadi sasaran perubahan atau refomasi. "Jembatan rasa" inilah yang dapat menghungkan komunikasi batin antara pembawa pesan dengan penerima pesan sehingga apa yang disampaikannya walau pahit akan dirasakan nikmat ibarat obat. Adanya sambung rasa yang menjembatani gagasan-gagasan ajaran lslam sebagai sistem budaya, dengan realitas masyarakat sebagai sistem sosial' akan membuat dakwah lebih mudah diterima oleh masyarakat, dapat lebih dimengerti oleh penerima dakwah. Sebagaimana dijelaskan dalam konsep perubahan sosial budaya' bahwa masyarakat akan menerima pesanpesan perubahan dalam rangka inovasi dan modernisasi, jika masyarakat memahami makna perubahan; masyarakat melihat ada nilai manfaat dari perubahan itu; serta tejangkau biaya untuk menerapkan teknologi sebagai salah satu wujud perubahan.

Berkaitan dengan kesadaran memahami tindakan individual yang bermakna Max Weber dalam Tom Campbell (1994: 199) menjelaskan bahwa ciri yang mencolok dari hubungan-hubungan sosial adalah kenyataan adanya hubungan-hubungan bermakna bagi mereka yang mengambil bagian di dalamnya. Bahwa kompleks hubungan-hubungan sosial yang tersusun dalam suatu masyarakat dapat dimengerti hanya dengan cara pemahaman ter-hadap segi-segi subyektif dari kegiatankegiatan individu para anggota masyarakat itu sendiri.

Pendekatan empali antuk bisa memahami perilaku seseorang dalam konsep tindakan sosial 'Weber, lebih dikenal dengan metode verstehen, yaitu metode pemahaman terhadap makna tindakan individu secara kualitatif. Karena itulah Maxweber berdasarkan rnodel pendekatan yang digunakannya sejak tahun 1904 sesungguhnya dapat dianggap sebagai pelopor model pendekatan kualitatif. Berbeda dengan Durkheim misalnya yang cenderung lebih banyak menggunakan pendekatan kuantitatif. Pendekatan kualitatif memang 
lebih bersifat subyektif karanaa pemahaman seseorang terhadap sesuatu bisa saja berbeda dengan pemahaman orang lain. Sebab itu Max Weber mengembangkan tipe ideal untuk menggambarkan sesuatu yang bersifat spesisifik (khas) dalam suatu kasus, kemudian digeneralisasikan secara umum.

Jadi untuk mengimbangi subyektivitas cara pandang kualitatif, juru dakwah dalam hal hal ini harus menemukan ciri-ciri umum yang dianggap ideal secara generalisasi. Untuk memahami tindalan sosial se-seorang secara kuatitatif, juru dakwah juga harus mempelajari latar belakang sosial budaya dan sejarahnya melalui pedekaan historis, bagaimana keadaan dulu dengan sekarang atau dibandingkan dengan kasus-kasus lain. Akurasi data kualitatif dapat di-lakukan dengan menggunakan banvak informan secara cross cek, minimal tiga orang (trianggulasi), secara redanden (berulang-ulang). Dalam Value Judgement in Sociological Science, Max Weber menggunakan pertimbangan nilainilai ideal sebagai alat ukur untuk bias memahami idealism tindakan masyarakat, Berbeda dengan cara pandang Kar lMarx yang menggunakan alat ukur materialism. Model pendekatan idealisme kualitatif Weber, lebih jelas dapat dipelajari lewat kajiannya tentang pengaruh agama (protestan) terhadap kehidupan ekonomi masyarakat. Dalam bukunya berjudul "The Protestant Ethic \& the Spirit of Capitalisme" (1906), Max Weber proposed the prevailing explanation for why capitalism arose in Europe. Firmly in the idealist camp, Weber linked capitalism to the Protestant Reformation. According to Weber, Protestantism supported values that fovored the occumulation of capital : Thrift, hard work, and material and spiritual salvation by means of individual effort (Mervin Harris, 1927: 165).

Dalam konteks ini Max Weber mengungkapkan adanya kecenderungan kelompok masyarakat Protestan "Calvijn" (Calvinisme) sebagai "good people goes to paradise heaven". Beberapa indikasi dari "good people" itu Antara lain, masyarakat yang bekerja keras, tridup hemat berjiiwa investasi, rasional, disiplin dan jujur, yang pada akhimya dapat membentuk kapital bagi kesejahteraan hidup sosial ekonomi masyarakat' Keadaan ini dijumpai di kalangan masyarakat Calvinisme, penganut setia ideologi \& etika Protestan, yang terbukti ratarata kehidupan sosial ekonominya 
lebih maju dibandingkan dengan komunitas lain. Dengan demikian Max Weber dapat membuktikan bahwa keyakinan ajaran agama ternyata marnpu membangkitkan semangat nasional masyarakat untuk menciptakan kondisi sosial ekonomi yang kuat. The religious forces at work in pastoral practice are the decisive influences forming national character (Runciman and Matthews, 1978: 138).

Penerapan dakwah dengan pola interaksionis fenomenorogis memberikan kesempatan terbuka seluas-luasnya kepada kedua belah pihak yang saling berinteraksi secara timbal balik' saling memahami perasaan dan pikiran, saling menghormati dan menghargai dalam penyampaian informasi, gagasan dan pesan, saling percaya akan hakikat kebenaran ajaran Allah, sehingga menimbulkan kepercayaan antara juru dakwah dan masyarakat.

Islam tidak menanam akar kepercayaan kepada orang-orong yang beriman, dengan mengisi keyakinan ke dalam hati mereka. Dengan cara seperti ini, agama kita membimbing para pengikutnya kepada ketenteraman dan kestabilan. Al-Qur'an menyatakan baha Rasulullah SAW., begitu yakin hingga orang-orang munafik me-ngecam beliau karena itu Islam juga memerintahkan kepada pengikutnya untuk saling percaya satu sama lain dan untuk menganggap niat-niat orang lain adalah baik Bila ma-syarakat saling percaya satu sama lain. Hal ini akan meningkatkan kecintaan mereka satu sama lain, dan membawa mereka kepada kehidupan yang yang harmonis (Sayyid Mujtaba Musavi Lari, 1990: 29).

Model dakwah interaksionis fenomenologis memungkinkan masyarakat melakukan kontrol dan introspeksi dengan penuh kesadaran terhadap dirinya sendiri, sehingga pada akhirnya ia bisa menghargai orang lain. Model pendekatan interak-sionis fenomenologis sekaligus mem-berikan peluang bagi pembinaan mental masing-masing pihak yang berinteraksi, untuk bisa memahami makna kehidupan yang sesungguhnya, sehingga juru dakuah dan masyarakat yang menerima dakwah dapat membatasi perilaku diri sesuai norma dan nilai-nilai sosial budaya, nilai-nilai kemanusiaan dan terlebih lagi nilainilai ajaran Islam. Dari kondisi seperti ini, tidak akan muncul juru dakah, mubaligh, kyai atau ulama yang hanya bisa mencaci maki seseorang di depan umum, menghujat menyalahkan bahkan menjatuhkan nama baik serta martabat 
seseorang, karena kesadarannya telah ikut melatrukan kontrol dan introspeksi terhadap dirinya sendiri.

Inilah hakikat model fenomenologis Alfred Vierkandt (1867-1953), sebagaimana diungkapkan oleh Don Mertindale (tt.: 74-75) bahwa Vierkandt membatasi konsep sosiologi sebagai ilmu yang mempelajari pluralitas suatu kelompok dan teori tentang interaksi sosial serta produk-produk aktivitas spiritual dan budaya. Bahwa metode fenomenologis terjadi karena penilaian yang terkontrol tentang proses kesadaran diri. Ia menuntut fokus perhatian pada aspek-aspek pengalaman yeng di-sadari dan tidak atas manifestasi eksternal.

Model ini menggambarkan sejenis "refleksi immanenf' dan konentrain terhadap makna yang inherent serta benda-benda yang bisa diamati apa adanya. Model fenomenologis berusaha menganalisis pengalaman-pengalaman seseorang, membahas disposisidisposisi sosial yang fundamental, serta mengasumsikan fondasi tersebut pada kehidupan masyarakat umum. Contoh-contoh analisis fenomenologis ditemukan di dalam disposisi tentang self respect (penghormatan sendiri) yang secara simultan menuntut adanya kejujuran sebagai suatu peraaan mendalam menyangkut superioritas yang pada akhimya dapat membangkitkan rasa hormat.

Model interaksionis fenomenologis menunjukkan adanya suatu ikatan dari dalam antara masyarakat atau kelompok yang berinteraksi, yang diekspresikan dalam wujud tindakan kepatuhan terhadap norma dan nilai-nilai sosial budaya yang telah disepakati. Model fenomenologis menyangkut kepatuhan, membuktikan adanya kesadaran dalam diri seseorang yang berinteraksi dengan pihak lain secara sukarela. Konsekuensi dari kesadaran diri itu secara psikologis akan melahirkan kepribadian superior, yang menuntut adanya kontak atau hubungan berdasarkan rasa cinta yang mendalam, melahirkan kesetiaan seseorang te-rhadap orang lain yang dianggap "berwibawa" serta memunculkan rasa hormat terhadap orang yang dijadikan panuh. Inilah sejenis partisipasi dalam kebebasan orang lain, sebuah naluri yang memanifestasikan dirinya untuk berkeinginan mengikuti pemimpin, mendengarkan ucapan, gagasan dan pendapatnya, sehingga timbul perasaan akan adanya ke-wajiban mematuhi "ceramah" pe- 
mimpinnya serta tunduk terhadap perintah dengan penuh kesadaran.

Model pendekatan interaksionis fenomenologis, lebih ditegaskan lagi oleh Alfred Schutz (18991959) berfungsi memeriksa dan meng-analisis kehidupan batiniah individu yakni pengalaman-pengalamanya mengenai fenomena atau gejala-gejala yang seringkali disebut "arus kesadaran". Bagaimana dunia kelihatan atau tampak pada indvidu dengan abstrak dari pernyataan-pernyataan kumulatif, berdasarkan ilmu pe-ngetahuan dan opini yang diterima, dan menghindari persoalan-persoalan ontologis mengenai apa yang "ungguh-sungguh" ada.

Alfred Schutz yang menggunakan piranti filsafat fenomenologis Edmund Huserl menjelaskan bahwa pengalaman tidak hanya diberikan kepada para individu melainkan bersifat intensional melibatkan orang lain yang memberikan pengarahan. Sehingga pengalaman masa lalu dan pengetahuan yang dicapai, menghasilkan apa yang disebut "apersepsi" atau pemberlam makna secara spontan kepada apa yang diberikan dalam persepsi indera. Jadi kesadaran yang tumbuh adalah kesadaran individu yang mengarahkan perhatainnya pda obyek-obyek tertentu.
Pola interaksionis fenomenologis sebagaimana dikembangkan oleh Schutz bertujuan untuk menemukan unsur-unsur kehidupan sosial, dengan cara menempatkan diri kita dalam pengalaman sosial orang lain. Dengan metode refleksi pengalaman sosial, akan tumbuh kesadaran diri sendiri ketika berinteraksi dengan orang lain dalam kehidupan sosial. Unmk bisa melalcukan intensi kehidupan sosial; kita harus menangguhkan atau memberikan kepercayaan terhadap kenyataan dunia di luar pengalaman kita sendiri, kita harus bisa meninggalkan segala prasangka terhadap masyarakat (Tom Campbell, 1994: 233).

Dengan demikian pola dakwah interaksionis fenomenologis, baru bias berhasil menumbuhkan interaksi positif antara juru dakwah dengan masyarakat yang menjadi obyek dakwah, jika kedua belah pihak "melepaskan" prasangka satu sama lain, bisa memahami tindakan individu sebagai pengalaman bermakna dari kehidupan sosial yang pemah dilalui. Kesadaran untuk mau memahami makna tindakan seseorang, akan banyak membantu bagi terwujudnya interaksi simbolik yang sekaligus dapat mendukung keberhasilan komunikasi dakwah. 
Our consideration of the place of meaning in social action begins with a discussion of three in-ferences which have been drawn from the general statement that shared, or culturally constituted, meaning entails symbols which stand for something in some res-pect; as we find each of these inferences to be eroneous, though fundamental to the methodological perspective of one or more schools of cintemporary culfural anthropology, the heart of the matterthe postulated relationship beiween meaning and realitycan be hrought into clearer focus. "

The first inference to be drawn from the observation that social meaning entails symbolic expression informs studies from a phenomenological, intuitionist, or hermeneutical perspective. This is the notion that meaning is the act of pointing or naming. As used, the notion implies the possibility of the independence of the experience of the actor and the real, obyective nature of the world and the posibility, moreover of indepen-dence between the experience of the same actor. Symbolic action is part of a total mode of production and expression of creative human energy. The only reference of sym-bolic action is to the other aspects of the creative enterpriset symbolic action may determine or be determined by, other aspects, of Social action, in any particular concrete empirical instance: but in theory, syimbolic action alay refer only it elf to other yimbolic action (Chneider, 1977: 19).

Model komunikasi interaktif juga dapat dilakukan dengan cara tatap muka seperti yang bisa dipelajari dari konsep interaksi sosiologis yang semula dikembangkan oleh. Georg Simmel (lahir di Berlin tahun 1853) berangkat dari kenyataan sosial yang dialami kebanyakan orang dengan cara yang paling langsung melalui interaksi tatap muka. Dalam interaksi tatap muka pada praktiknya dapat dilakukan dalam jumlah besar antara seorang ulama dengan masyarakat terbuka ratusan atau ribuan orang, tetapi tentu saja efektivitasnya akan jauh berbeda dengan interaksi tatap muka yang dilakukan antara seorang ulama dengan ummatnya dalam jumlah yang lebih kecil atau terbatas. Kita dapat melihat dengan mudah pentingnya dinamika-di-namika yang tidak kentara dalam proses 
interaksi pada tingkat tatap muka dalam kehidupan individual. Beberapa tantangan utama yang kita hadapi, baik berupa kegembiraan yang meluap-luap makin kekecewaan yang pahit terjalin sangat erat dengan serangkaian pertemuan dan hitungan sosial di mana drama kehidupan pribadi kita terungkapkan.

Namun bagi kebanyakan orang kelihatannya ada suatu pemisahan yang tajam antara dinamika-dinamika yang tidak kentara dan berbelit belit dalam pertemuan tatap muka, serta hubungan-hubungan prlbadi di satu pihak dengan struktur sosial atau institusi sosial yang besar di lain pihak struktur-struktur besar sering kelihatan abstrak dan jauh dari proses-proses sosial di mana kita terlibat setiap hari. Dinamika hubungan antar pribadi dalam tatap muka sering kelihatan lebih menarik serta menggairahkan untuk dipelajari, mungkin karena kenyataan tingkat sosial ini ketihatan lebih langsung relevansinya daripada kenyataan struktur sosial yang besar.

Bagi Simmel, strukltur sosial yang besar atau institusi pertemuan atau hubungan tatap muka tidak semuanya independen, Institusi sosial tidak memilik eksistensi obyektifnya sendiri; terlepas dari pola interaksi yang membentuknya.

Sebaliknya struktur sosial atau institusi merupakan bentuk atau pola interaksi yang sudah mapan dan bisa diikuti oleh kalangan luas dalam masyarakat. Akibatnya institusi atau struktur sosial itu mungkin kelihatan mengonfrontasikan individu sebagai kenyataan obyektif di-mana individu harus menyesuaikan dirinya. Simmel memusatkan perhatiannya pada dinamika-dinamika yang tidak kentara yang mendasari pelbagai bentuk interaksi antar pribadi, tetapi bentuk-bentuk ini merupakan bahan dari mana struktur sosial itu akan terjadi.

Georg Simmel merupakan ahli teori ktasik terkemuka yang mempelajari proses interaksi di tingkat mikro. Berbeda dengan August Comte yang menekankan tingkat budaya dalam kenyataan sosial, khususnya tahap-tahap perkembangan intelektual. Sedangkan Karl Marx dan Emile Durkheim memusatkan perhatiannya pada tinghkat struktur sosial, meskipun keduanya be\$eda secara substansial dalam tekanan utamanya. Sementara Max Weber menggambarkan dasar pemikirannya pada kenyataan sosial yang menekankan individu serta tindakan sosial bermakna secara 
subyektif; namun analisis substansinya sangat banyak berhubungan dengan tingkat struktur sosial budaya, termasuk pola-pola perubahan sejarah masyarakat. Simmel menekankan tingkat kenyataan sosial yang bersifat antar pribadi (interpersonal), karena dia yakin bahwa perkembangan sosiologi sebagai suatu disiplin tersendiri menuntut pengendalian terhadap dua pandangan yang saling bertentangan, yakni antara realisme dan nominal-isme. Posisi realis (seperti tercermin dalam Durkheim) menekankan bahwa struktur sosial memiliki eksistensinya sendiri yang riil dan obyektif, terlepas dari individu yang mungkin kebetulan terlibat di dalamnya. Jadi masyarakat membentuk suatu keseluruhan yang lebih besar daripada jumlah bagian-bagianya. Sebaliknya posisi nominalis (seperti tercermin dalam definisi Weber mengenai sosiologi) menekankan bahwa hanya individulah yang riil secara obyektif, sedangkan masyarakat tidak lain hanyalah suatu kumpulan individu dengan perilakunya. Dalam pandangan ini struktur sosial cenderung dijelaskan menurut sifat-sifat individu atau tujuan-tujuannya secara sadar.
Menurut Georg Simmel dalam posisi poros tengah yang berada di antara kedua ekstrim itu melihat bahwa masyarakat lebih dari pada hanya sekadar suatu kumpulan individu dengan pola perilakunya; namun masyarakat tidak independen dari individu yang membentulkannya. Karena masyarakat menuniuk pada polapola interaksi timbal balik antar individu - Pola-pola seperti itu bisa menjadi sangat kompleks dalam suatu masyarakat yang besar dan bisa kelihatan sangat riil secara obyekytif pada individu. Tetapi, tanpa pola interaksi timbal balikyang berulang-ulang sifatnya, kenyataan masyarakat itu akan hilang. Meskipun George Simmel terutama memperhatikan pola interaksi yang kecil stfatnya, perspektifnya dapat iuga diperluaalre insfiusi sosial yang lebih besar (Doyle Paul Johnson, 1986: 257).

Berdasarkan konsep interaksi timbal balik dalam bentuk tatap muka yang diungkapkan oleh George Simmel, maka pola interaksionis fenomenologis dalam rangka dakwah Islam dapat lebih intensif dilakukan melalui interaksi antar individu dalam kelompok mikro, yang selalu bertemu dan bertatap muka secara berulangulang, sehingga hubungan batin antara juru dakwah dengan 
kelompok yang menjadi obyek dakwah akan lebih terjalin dengan baik. PoIa dakwah interaksionis fenomenologis model ini barangkali dirasakan lebih intensif mencapai keberhasilan dakwah Islamiyah, karena gagasan-gagasan ajaran agama- norma serta nilainilai Al-Qur'an lebih mudah dicerna, dicermati, ditelaah, serta diterima setelah melalui proses dialog atau tanya jawab secara mendalam.

Dari pengalaman sejarah, dakwah model interaksionis fenomenologis yang diterapkan oleh Nabi Muhammad SAW. telah membuktikan intensifikasi komunikasi yang berhasil membuahkan para sahabat setia; kuat iman dan takwanya, serta tekun ibadah dan ikhlas pengabdiannya, dihiasi akhlaq al-karimah. Model dakwah interaksionis fenomenologis yang dilakukan oleh Rasulullah SAW., juga telah berhasil menciptakan kerukunan hidup beragama antar golongan yang berbeda di Madinah.

Toleransi sosial masyarakat Islam terhadap masyarakat lain yang berbeda agama, menjadi cermin kehidupan sekaligus contoh keberhasilan dakwah. Hampir tidak ada masalah kehidupan sosial budaya yang tidak terpecahkan pda masa Nabi, karena secara terbuka
Rasulullah memberikan kesempatan dialogis secara interaksionis fenomenologis. Gejala-gejala perbedaan, pertentangan bahkan persaingan yang tajam bukan tidak ada, tetapi semuanya bisa diselesaikan melalui dialog yang interaktif antara Nabi sebagai juru dakwah dengan para sahabat dan umrnat yang berbeda agama sekalipun sebagai obyek dakwah pada masa itu. Dialog beranjak dan anggapan bahwa tiap-tiap agama tuntutan mutlak yang tidak dapat dinisbikan. Perumusan kembali tidak akan menghilangkan perbedaan: Namun, dengan membiarkan pem-bahasan teologi kita dipengaruhi teologi agama lain. Sehingga kita terpaksa menjadi makin jujur dan lebih memperdalam kehidupan rohani kita. Prasyarat untuk dialog bukanya penyelarasan semua keyakinan, melainkan pengakuan bahwa tiaptiap beragama memiliki keyakinan yang teguh dan mutlak, dan bahwa keyakinan-keyakinan ini berbeda (Harold Coard, 1994: 75).

\section{E. Penutup}

Pola dakwah interaktif fenomenologis adalah model penyampaian pesan ajaran agama secara dialogis, di rnana da'i atau juru dakwah secara terbuka berkomunikasi timbal balik dengan 
masyarakat sebagai obyek dakwah. Masyarakat secara terbuka dapat menyampaikan masalah-masalah aktual yang mungkin sangat urgen bagi kehidupan mereka, dan para da'i selalu siap untuk memberikan jawaban memperkuat iman dan takwanya kepada Allah SWT. Melalui interaksi fenomenologi para da'i dituntut untuk memahami makna prilaku masyarakat yang dijadikan sasaran dakwahnya, sehingga tercipta "Jembatan rasa antara juru dakwah sebagai agent of reformation dengan masyarakat yang menjadi sasaran perubahan atau refomasi.

\section{DAFTAR PUSTAKA}

Ali Aziz, M. 2004. Ilmu Dakwah. Jakarta: Prenada Media.

Campbell, Tom. 1994. Tujuh Teori Sosial, Sketsa, Penilaian, Perbandingan. Yogyakarta: Kanisius.

Craib, Ian. 1992. Teori-teori Sosial Modern. Jakarta: CV. Rajawali.

Dedi Mulyana. Komunikasi antar Budaya. Bandung: PT. Remaja Rosdakarya.

Harris Marvin. 1997. Theorities Of Culturein Postmodern Time,
Altamira Press A Division of Sage Publication. New York Delhi: Inc. Walnut Craek Londons.

Lauer, H. Robert. 2000. Perspektif Tentang Perubahan Sosial. Jakarta: PT. Rineka Cipta.

Lawang, Robert. 1994. Buku Materi Pokok Pengantar Sosiologi. Jakarta: Universitas Terbuka.

Narwoko, J. Dwi dan Bagong Suyanto. 2005. Sosiologi Teks Pengantar dan Terapan. Jakarta: Kencana Prenada Media Group.

Nasir, Nasrullah. 2009. Teori-teori Sosiologi, Bandung: Widya Padjadjaran.

Poloma, M. Margaret. 2000. Sosiologi Kontemporer, Jakarta: CV. Rajawali.

Raho, Bernard. 2007. Teori Sosiologi Modern. Jakarta: Prestasi Pustaka.

Soekanto, Soerjono. 1993. Kamus Sosiologi, Jakarta: PT. Raja Grafindo Persada.

Toha Yahya Oemar. 1992. Ilmu Dkwah, Wijaya. Jakarta. 